\title{
APRESENTAÇÃO
}

\section{ESTABELECENDO DIÁLOGOS ENTRE O PASSADO E O PRESENTE: REFLEXÕ̃S SOBRE NOVAS PERSPECTIVAS NA ARQUEOLOGIA BRASILEIRA}

\author{
Flávio Rizzi Calippo
}

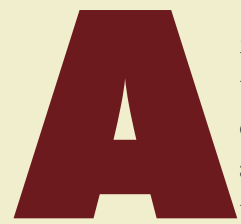

imagem da arqueologia, durante muito tempo, esteve associada, mesmo em algumas áreas do meio científico, à simples ideia de que o arqueólogo é aquele pesquisador que se desloca a lugares remotos para coletar os objetos deixados por culturas passadas. De certo modo, existe alguma verdade nesta compreensão. Entretanto, nas últimas décadas, tanto no Brasil como no mundo, a arqueologia vem se repensando e assumindo novas reflexôes e discursos em relação ao passado e aos seus objetos de estudo. O propósito dos artigos apresentados neste Núcleo Temático é mostrar alguns exemplos dessa nova tendência da arqueologia, que amplia cada vez mais seus domínios para além do estudo dos objetos e de um passado distante, e busca, principalmente, dialogar com outras áreas do conhecimento para poder tecer, com base no estudo das sociedades do passado, reflexões e discussões a respeito dos problemas e das questôes que vivemos no presente.

O propósito não é apresentar uma abordagem abrangente e completa de toda a arqueologia praticada no Brasil, mas, sim, mostrar ao público em geral e aos pesquisadores de outras áreas, que a arqueologia é uma ciência que cada vez mais se esforça para estabelecer uma visão própria a respeito dos problemas brasileiros e dos contextos onde os arqueólogos atuam, para dialogar com a sociedade, para socializar os conhecimentos produzidos no âmbito acadêmico e para atuar ativamente na proteção, na gestão e uso público do patrimônio cultural e arqueológico.

Sob tal perspectiva, a arqueologia será abordada em nove artigos. No primeiro deles, Pedro Paulo Funari discute algumas das principais temáticas que vêm sendo propostas no âmbito da arqueologia brasileira e mundial. Em seguida a ele, Ângelo Corrêa e Diogo Costa, desenvolvem em seus respectivos artigos novos olhares arqueológicos a respeito da história das naçōes indígenas e sobre as relaçôes estabelecidas entre essas sociedades, o colonizador europeu, os povos africanos e os imigrantes europeus, desde o período do contato até os dias atuais. Abordando discussões mais contemporâneas, Flávio Calippo, Gilson Rambelli e Paulo Bava de Camargo discutem problemáticas relativas à proteção e gestão do patrimônio cultural subaquático. Nessa mesma linha patrimonial, Gilberto Francisco ressalta a importância dos estudos clássicos para o entendimento de práticas atuais.
Nos quatro últimos artigos, desenvolvem-se textos que procuram estabelecer uma relação mais próxima da arqueologia com as comunidades e com o público. Helena Lima e Bruno Moraes falam a respeito das possibilidades e das problemáticas que se estabelecem quando a prática arqueológica é inclusiva e os agentes e os saberes locais são reconhecidos e incorporados à pesquisa. Louise Alfonso e Anne Py-Daniel ressaltam a importância das narrativas produzidas pelas populações locais para o trabalho dos arqueólogos e para o turismo cultural. Aline de Carvalho e Bruno da Silva discutem, utilizando a figura do Indiana Jones como interlocutor, caminhos para o estabelecimento de ações de socialização do conhecimento. Por fim, Camila Delmondes Dias, Cristiane Delfina, Glória Tega-Calippo, Maria Beatriz Rocha Ferreira e Vera Regina Toledo Camargo, a partir do olhar do jornalismo científico, estabelecem críticas e reflexões a respeito da divulgação do conhecimento produzido pela arqueologia.

Ainda que essa nova tendência de se pensar a arqueologia tenha recebido, em parte, influências teóricas desenvolvidas por pesquisadores estrangeiros para a discussão de problemáticas específicas de outras regiōes, tais perspectivas vêm se estabelecendo, no Brasil, de forma crítica, reflexiva e direcionada aos diferentes contextos culturais, históricos e arqueológicos que vêm se formando desde a pré-história. Se existe um motivo pelo qual a arqueologia vem despontando no cenário internacional é justamente pela preocupação e pelos esforços em se estabelecer compreensōes que extrapolem o entendimento do comportamento humano como algo normativo e em consequência do desenvolvimento de reflexôes arqueológicas que contribuam para a discussão de nossos problemas atuais.

Flávio Rizzi Calippo é professor do Curso de Arqueologia e Conservação de Arte Rupestre e dos Programas de Pós-Graduação em Arqueologia e Antropologia, todos da Universidade Federal do Piauí(UFPI).Email: calippofofr@ufpi.edur.br 